\title{
João Antônio: cartas de desabafo
}

\author{
Fernando Paixão ${ }^{1}$
}

João Antônio era um homem (e escritor) dotado de sentimentos e convicções que se mantiveram pela vida inteira. Indivíduo agarrado a algumas opiniões, disposto a defender um princípio ético para o ato de escrever, costumava dizer o que pensava, mesmo que viesse a desagradar amigos ou a boa conduta. Nas rodas que frequentava, alguns até podiam enxergá-lo como alguém "abraçado ao seu rancor”, expressão criada para o título de um de seus livros.

Por vezes, costumava se exaltar e vociferava contra isto ou aquilo, deixando brilhar a raiva nos olhos. Ou então, no mais das vezes, sucedia o contrário: transformava-se numa pessoa generosa, delicada e de refinado gosto pelos detalhes e coisas pequenas. Gostava do contato humano, seja com a mendiga louca que frequentava a praça Serzedelo Correia, onde morava; seja com os diversos amigos escritores com quem mantinha diálogo. No mais, tinha de ganhar a vida e o fez em grande parte por meio de continuada colaboração na imprensa.

Era a literatura, porém, que estava no centro de sua vida e dedicação. Durante anos, acalentou a ideia de escrever um "Tratado sobre as gaivotas", pelas quais nutria verdadeira paixão. No fim das tardes, tinha por hábito visitar a praia de Copacabana, principalmente para ficar admirando o movimento das aves. Mas o tratado nunca chegou a termo, embora o escritor tenha deixado algumas anotações a respeito. Nascido na capital de São Paulo, em 1937, João Antônio publicou na imprensa os seus primeiros textos literários, antes dos 20 anos de idade. Trabalhou como operário, bancário, redator de publicidade e depois como jornalista, função que veio a exercer até o fim da vida. Sempre esteve ligado à gente humilde da periferia, legado que recebeu da vivência nas ruas de terra, em meio ao casario pobre de Presidente Altino, Osasco, onde residia sua família. Tinha orgulho da herança portuguesa recebida do pai - que levou-o a ter especial ouvido para a sintaxe lusitana - e sempre se lembrava de Dona Nair, a avó, cultuada acima de todos por sua bondade e sabedoria.

Em 1963, estreia com um livro, que teve de ser reescrito, por força de um incêndio ter desaparecido com os originais: Malagueta, Perus e Bacanaço. Nele, o texto principal apresenta uma crônica urbana em

1 Docente da área de Literatura do Instituto de Estudos Brasileiros da Universidade de São Paulo. E-mail:fernando.paixao@usp.br 
torno de três jogadores de sinuca, bons de prosa e de malandragem. Teve ótima acolhida por parte da crítica, mas também do público, receptivo para aquele singular estilo de frases curtas, capaz de entremear a oralidade das falas com um narrador certeiro e arguto. Nos dizeres de Antonio Candido, a cidade paulistana dos seus contos aparece quase sempre relacionada a personagens "marginais moídos pela vida, procurando meios de sobreviver por meio da trapaça, da esperteza ou da brutalidade"2.

Voltou a publicar ficção na década seguinte, com destaque para os contos de Leão de chácara (1975), ganhador do Prêmio Nacional de Contos do Paraná. Com esse livro, recebeu ainda outros prêmios e ficou na lista dos mais vendidos por mais de dezesseis semanas, coisa rara para um escritor brasileiro. Estimulado pelo sucesso e pela intensa atividade jornalística que mantinha naquela época, prosseguiu com o lançamento imediato de Malhação do Judas carioca (1975) e, no ano seguinte, Casa de loucos (1976); ambos inspirados em fatos e lugares reais. No entanto, eram livros diferentes dos anteriores, reunindo contos, reportagens, depoimentos, perfis etc. Nesses casos, o ficcionista cedeu vez ao repórter de perfis humanos, e o próprio autor tinha consciência disso ${ }^{3}$.

Com o recrudescimento da censura, e o crescente apelo por liberdades democráticas, João Antônio tornou-se referência nacional. Aparecia com frequência nos jornais alternativos e publicava textos na imprensa "nanica" (termo por ele criado no semanário Pasquim). Natural, então, que se transformasse num representante-símbolo entre os chamados "escritores malditos", movimento que mesclava um conjunto bastante difuso de autores preocupados em denunciar as mazelas da ditadura militar. Ele mesmo, contudo, não gostava de rótulos e dizia que a boa literatura está longe de qualquer determinismo de ordem política.

Voltou à literatura em 1980, quando publicou os contos de Dedo duro (1982) e Meninão do caixote (1983), sem obter a mesma consagração dos livros anteriores. Particularmente no segundo, o narrador ganha em lirismo, sugestionando uma espécie de melancolia próxima da atenção poética. Nesse sentido, é primoroso o conto que dá título ao livro.

2 CANDIDO, Antonio. Noite enxovalhada. Revista Remate de males, Campinas, Unicamp, n. 19, p. 83-88, 1999 .

3 Conforme carta a Caio Porfírio Carneiro, em dezembro de 1975: "Não acredito, sinceramente, que eles venham a ter o mesmo sucesso de Malagueta, Perus e Bacanaço e de Leão-de-chácara junto à alta crítica brasileira. Provavelmente dirão alguns que estou partindo para certa facilitação e aproveitando, com rapidez e gula, o sucesso nacional de meu nome, no momento... No entanto, tanto em Malhação do Judas carioca quanto em Casa de loucos, tenho a consciência bastante tranquila. Trabalhei honestamente, dei às matérias um cunho não datado, procurei transformar o factual e o circunstancial em dimensões de documento para valer com alguma perenidade". In: ANTÔNIO, João. Cartas aos amigos Caio Porfírio Carneiro e Fábio Lucas. São Paulo:Oficina do livro/Ateliê editorial, 2004. p. 64 . 
Sua última obra de fôlego foi Abraçado ao meu rancor (1986), na qual o tom lírico se acentua, voltado para a memória e certo desencantamento. Como resultado, temos uma escrita de homem maduro, mais atenta ao viés psicológico, sem abdicar da visão cruel que denunciava nas relações sociais e na violência urbana. Foi, provavelmente, ao escrever os contos desse livro, inspirado por certo toque experimental, que ele consolidou a visão de mundo que o acompanhou no período final de vida.

Conheci João Antônio em meados dos anos 1980, mas foi somente na década seguinte que mantivemos maior proximidade. Tive a iniciativa de publicar duas coletâneas de contos dele ${ }^{4}$, e a convivência rápida nos tornou íntimos. Quase sempre que vinha a São Paulo, deixava uma saudação na secretária eletrônica, já contando com os nossos tradicionais encontros em que o almoço se estendia até o fim da tarde.

"Literatura é uma coisa muito séria", dizia ele, "tem de vir junto com o sangue, senão fica sendo só mijada." Dessa maneira direta, e por vezes desbocada, ele referia-se a isto ou aquilo, disparando diatribes contra os governos ou os editores oportunistas. Seu modo de pensar e agir tinha forte inspiração na figura de Lima Barreto, como se sabe. Em certa medida, João Antônio procurava mesmo reencarnar o criador de Policarpo Quaresma. A eclosão de seus olhos irados, por vezes, denunciava isso.

Cultivava ainda a leitura dos clássicos e volta e meia retornava ao convívio dos escritores portugueses, dentre os quais se destacavam Eça de Queiros e Ramalho Ortigão. Tinha também especial apreço pelas questões da língua e era muito sensível aos aspectos técnicos da escrita. E quando essas conversas estavam acompanhadas da aguardente, o bom humor era inevitável: "Os árabes são tão chegados à prática amorosa ao modo deles, claro: carnal, cheio de volumes e reentrâncias - que têm perto de noventa palavras usadas como sinônimo de amor. Quanta variedade! Podem até fazer um trem com essas palavras todas, enfileiradas."

Pouco antes de falecer, em outubro de 1996, devido a problemas cardíacos, passou por um período um tanto angustiado. Tendo que escrever textos jornalísticos para completar o orçamento, sentia-se travado para voltar a escrever literatura. Ao mesmo tempo, não conseguia vestir muito bem o figurino do escritor convidado para congressos, encontros literários e coisas assim. Aceitava os convites, mas com o sentimento dividido entre a vontade de se comunicar com o público e a impressão de que eram tertúlias levianas e inúteis.

4 Malagueta, Perus e Bacanaço (Editora Ática, 1986); Patuléia (Editora Ática, 1991), em edições esgotadas. Atualmente a obra de João Antônio vem sendo publicada pela editora Cosac Naify, que fez uma edição especial de Malagueta, Perus e Bacanaço, entre outras. 
Vale lembrar ainda que, durante a década de 1990, ele passou por algumas adversidades junto a editores. Ainda que fosse um autor premiado e conhecido do público, traduzido em diversos países, seus livros iniciais estavam esgotados no Brasil e ele não encontrava editora para republicá-los. Do ponto de vista financeiro, ganhava pouco com a literatura. Para complementar o orçamento, voltou a dedicar-se à imprensa, escrevendo crônicas e longos perfis de compositores e figuras populares. Os últimos livros que publicou resultam novamente da mescla entre o jornalista e o escritor: Zicartola (1991) e Dama do encantado (1996).

Alguns meses antes de seu falecimento, com o intuito de estimulálo a organizar as ideias, tivemos um encontro em que propus a ele o desafio de escrever algo que expressasse um depoimento pessoal sobre a arte literária. Coisa pequena, próxima ao ensaio longo, mas que apresentasse o autor sob ângulo novo. Provoquei-o até com o argumento de que o Lima Barreto havia escrito bastante sobre a sua visão de literatura e ele também poderia fazer algo assim, seguindo os passos do mestre. Afinal, ele já tinha dentro de si toda uma maneira de pensar o ofício; bastaria sistematizar o pensamento no papel.

Diante da proposta, o seu primeiro instinto foi o de recusa. "Sou escritor e não crítico", respondeu. Foi aí que me ocorreu citar o livro de Julien Gracq, A literatura no estômago, que podia servir-lhe de referência. Eu descobrira esse texto alguns anos antes e, desde a primeira leitura, conduziu-me a uma associação com o autor de Leão de chácara, sobretudo pelo tom incisivo e polêmico com que trata o campo literário na França, após o fim da Segunda Guerra.

Publicado inicialmente na revista Empédocle, em 1949 (e no ano seguinte, na forma de livro), o panfleto de Gracq realiza uma crítica ácida em torno dos mecanismos de legitimação literária daquele período, denunciando a troca de interesses e a propaganda subliminar como forma de estabelecer uma hierarquia de valores. $O$ autor fancês enfatiza ainda o fato de o público ter-se acomodado ao veredito da crítica ou da lista de best sellers, publicada nos jornais. Desse modo, o leitor comum abre mão do gosto individual e da descoberta literária, conformado com o que sugerem os chamados especialistas.

Adepto de opiniões semelhantes, não foi necessário argumentar muito para mudar a posição inicial e refratária de João Antônio. Mostrou-se interessado em ler o livro e prometeu pensar no assunto. No dia seguinte, mandei-lhe o exemplar de uma edição portuguesa, que tinha em casa ${ }^{5}$. Eu sabia que, naquele momento, ele se encontrava longe do deslumbramento de seus primeiros anos de vida literária; ao contrário,

5 GRACQ, Julien. A literatura no estômago. Lisboa: Assirio \& Alvim, 1987. 
tornara-se um tanto amargo, desencantado com as rodas literárias em que via predominar a vaidade dos escritores sobre a discussão de ideias e valores literários. Considerava isso um traço de provincianismo do meio literário tupiniquim.

Nas semanas seguintes à nossa conversa, a leitura de Julien Gracq desencadeou um rastro de pólvora na cabeça de João Antônio. Tal ebulição ficou registrada nas cartas que ele me enviou na ocasião, envolvido com o desafio de pensar "de fora” o meio literário onde vivia. Essas correspondências, datilografadas e corrigidas com sua letra miúda, expressam um verdadeiro desabafo, provavelmente intensificado pelas dores nas costas, de que se queixava com frequência. Junto a uma delas, enviou também uma espécie de texto-manifesto, certamente inspirado no autor francês, e cujo título fala por si: Olhar baço da literatura engambelada.

Na época, ele se aproximava dos sessenta anos, com o espírito menos romântico que na juventude e consciente de que era necessário descobrir novos rumos para a arte literária. Algo que não caísse em receitas ou fórmulas prontas. Num dos trechos, diz:

Sei que não é nada fácil se mexer, sobreviver, refletir esse miserê, pois estamos em pleno caos. Uma linguagem para tudo isso é desconhecida. Deve ser tão nova e aguerrida que fica bem para lá de insólita. Ou arrepiante. Os temas são evidentes, ostensivos, estão aí. Mas podem fugir como enguias, são ariscos e exigem que se vá fundo neles.

Três meses depois, ele viria a ser encontrado morto em seu apartamento, vítima de ataque fulminante. Interrupção abrupta de toda uma inquietação criativa.

Suas cartas, incluindo algumas outras de menor importância, ficaram na gaveta até o presente. Passados os anos, penso que a pequena história contada aqui ilustra de maneira exemplar a força e tenacidade do projeto literário de João Antônio, adepto de uma visão de literatura que não abria mão dos valores estéticos e procurava sintonia (e compaixão) com o comum das gentes. Acreditava ele que o escritor tem mesmo um papel a cumprir no meio social e que a base de sua atuação está nas ideias e nas palavras - quando se toma posição, longe dos rebanhos de "maria-vai-com-as outras".

Nesse sentido, chama a atenção o modo crítico e enfático como ele assinala as mazelas do meio à sua volta. Escritores vaidosos e autoreferidos, dotados de altas doses de narcisismo e sutis interesses de propaganda, são o seu alvo preferido a ser condenado. Sente-se rodeado por muitos dessa espécie. Linhagem, aliás, produtora do que ele qualifica 
de "literatura engambelada", dissimulada, com aparência de altas literatices, e que em verdade rouba espaço e aura de uma necessidade vital ligada à imaginação coletiva.

A engambelação, por sua vez, bem se sabe, não é privilégio do passado. Sob certa medida, faz parte intrínseca do funcionamento do chamado campo literário, inclusive atual, sobretudo quando visto sob a ótica das celebridades e dos best-sellers. É preciso sempre estar atento a ela, para não se ler gato por lebre. Razão pela qual o diagnóstico apontado por João Antônio nestas breves páginas dá muito o que pensar sobre o estado presente das coisas. Ao acusar de "não-literatura" a boa parte dos textos e autores que se apresentam como tal, ele afirma, por outro lado, o caráter experimental e dramático da escrita, quando se volta para testemunhar o seu tempo. Assunto esse que nos levaria por outras veredas.

Optamos por apresentar o texto integral das cartas, sem notas adicionais, porque o propósito aqui não está associado à exegese do documento e sim ao caráter de testemunho que representam. A leitura sem mediações críticas tem a vantagem de nos colocar em contato direto com a sinceridade e a bilis do autor, aspecto que se faz importante neste caso.

Sem meias palavras, e abraçado a certa dose de rancor, o desabafo de João Antônio tem a qualidade (e a coragem) de por o dedo em importantes feridas da literatura brasileira. 


\section{Carta 1}

\section{Copacabana chuviscosa, 12/3/1996.}

Fernando Paixão. Prezado.

Depois do nosso telefonema me veio vontade de conversar com você. O ambiente está pra lá de ruim, abaixo de cu de cachorro conforme dizia o falecido Narciso Kalili, de inesquecível memória. Assim é. E pouca vontade tenho de conviver com tais enxames. A acrimônia tomou conta, a maledicência acompanhou e a fatuidade tirou patente. Num tempo em que, se diz, não se tem tempo mais pra nada, essas curriolas encontram tempo pra falar mal de tudo. E também do que não leram ou viram. Tenho, pois, certa vizinhança faladeira querendo me aporrinhar.

Não bastassem os meus enroscos, dores e miasmas. A vontade me vem de mandá-los tomar num lugar onde o sol não bate; ou lamber sabão; ou pentear macacos ou passar sal na bunda. E, pelo caminho, aproveitando a passagem, irem à merda. Tudo isso, antes que eu me esqueça.

Quero ficar só com as coisas minhas. Muito mais que lindas, diria o poeta. Tenho boas companhias por aqui. Desde os caquis que vou comendo, pois a temporada é deles, até alguns ensaios supimpos que tenho lido graças à Maria José de Queiroz, que escreve elegante e límpido, é culta e não bota banca, dá uma de vagamunda e é uma senhora ensaísta. Ensiname e me convida a pensar. Tão diferente da gentalha ou gentarada que gosta de aparecer e encher as medidas e desmedidas. Egões, conforme v. mesmo diz. Quero distância deste festival das vaidades arreganhadas. E dos anseios ressentidos. Deus me livre e guarde e toda a casa de Davi me salve. De assim, quero ir cada vez menos aos lugares frequentados pela curriola dita letrada. Hei de fugir deles como o diabo da cruz. E, em os vendo, me persignarei três vezes - na testa, na boca e no peito. $\mathrm{O}$ ambiente dos letrados está pra lá de Deus me livre. Imagino um sujeito barbado, magro e alto, com um relho na mão invadindo esses ambientes infectados e descendo o relho em todos os asquerosos. E aos gritos quase bíblicos:

- Ímpios e fariseus, ide lamber sabão com a vossa acrimônia! E o Diabo os tenha para todo o sempre, mediocrões e ignorantaços! Não passais de reles preguiçosos a dormir no travesseiro de Satanás.

Ah, baixou-me aqui no domingo certa B. E. ${ }^{6}$, vinda de Heidelberg, que faz uma monografia sobre a gíria nos contos modernos brasileiros e, caprichosa, parece-me. Incluirá uma tradução comentada do meu contotítulo "Leão-de-Chácara" para o Instituto de Tradutores e Intérpretes de lá. Já estive nesse instituto algumas vezes para falar e debater. A moça branca como um copo de leite, sem chances de me falar à sensualidade,

6 Por questão de privacidade, optou-se por abreviar o nome citado aqui. 
pois. Ficou aqui o dia quase inteiro, umas nove horas. Anotando tudo, como fazem os alemães, folhas e mais folhas. Escolheu logo um texto intraduzível, a meu ver. E foi preciso, Fernando, que eu tivesse longa conversa com ela explicando-lhe o que é a gíria brasileira no meu pobre entender. Há que se descer à Argentina, à Boca de Buenos Aires e frequentar o lunfardo que aprendi, antes de 1960, aí em São Paulo, graças a um amigo, Victor Taphanel e sua mulher Luzia. Esse Taphanel sacava o Brasil, ouvia Noel Rosa e conhecia até o Ricardo Coração dos Outros, de Lima Barreto. O argentino passou-me o gosto pelo lunfardo e me deu dois livros de Roberto Arlt, o autor de Os Sete Loucos, romance profético, escrito antes de 1948 e que prevê toda a merdalhada que se abateria sobre a Argentina. Faz profecias extraordinárias e acerta na mosca quase tudo. Figuras como lsabelita e seus ministros numa aparente figuração de opereta bufa em que entram personagens fantásticos como o Rufião Melancólico e o Astrólogo. Tudo isso escrito em lunfardo. Esse Roberto Arlt é muito considerado lá até por J. L. Borges.

Como deve ser difícil traduzir gíria para uma língua que não tem gíria! Mas a moça era insistente e disse que topou o desafio. Teve uma outra, certa ocasião, aqui fazendo um trabalho parecido para o mesmo instituto de Heildelberg. Traduziu-me "Mariazianha Tiro-a-Esmo", que depois apareceu numa antologia. Mas, apesar tudo, não ganhou nota boa, sei lá, devido às exigências do professor. Acho uma maluquice danada um alemão se meter a traduzir um conto como "Leão-de-Chácara”. E, assim, me foi embora o domingo. Como chuviscasse, até me distraiu.

Creio que a tal B. E. saiu daqui bem tonta e, depois, me deu pena. Branquela e com ares de estrangeira, fumando muito, confessou-me medo de andar pela Copacabana noturna e tive de acompanhá-la até a Rua Santa Clara onde está parando em casa de amigos. É uma raça obcecada, Fernando, e pouco os entendo. Sei lá. Dois mundos, duas culturas, duas histórias e, muita vez, lamentei não ler o alemão. Creio que se eu lesse um Goethe ou um Schiller no original teria maiores possibilidades de entender aquela gente. Sei lá. Lendo esses e mais alguns no original, um Musil, um Gunther Grass, quem sabe aí é que não entenderia mesmo os alemães.

Sei não. Quando voltei a Berlim, uma das vezes, havia uma exposição de um grande mestre da pintura e da gravura, Albrecht Dürer. Um peso pesado, tanto que todo o dinheiro alemão, inclusive o atual, tem desenhos tirados dele. Esse sujeito nascido em Nuremberg (estive na casa dele) tem umas cartas deliciosas e fortes, umas Cartas da Itália. São de uma sinceridade que jorra e ele diz, abertamente, que só se sentia ele mesmo debaixo do sol da Itália devido ao sol e à luminosidade. Fora do solo italiano se sentia um impostor e um estrangeiro. Eu gostaria de 
ler essas cartas, mas não leio alemão. E nem é hora de aprender. Se você souber de alguma tradução dessas Cartas da Itália para o português, me avise. Sabemos que a barra da pintura não é brincadeira. Esses caras, quando autênticos, perseguem suas coisas até encontrá-las. Acabam encontrando outras pelo caminho e deve ser uma tortura de verdade. E no caso alemão, com a mania do perfeccionismo, a parada fica séria. Acabam, creio, vivendo fortes ou terríveis aventuras do espírito.

Não gosto de trabalhar de graça num domingo, creio que ninguém gosta. Mas se eu não ajudasse B., quem o faria? Foi bom. Eu esclareci a ela que muita palavra que uso não é gíria, está tudo dicionarizado até no Aurélio que é, afinal, um dicionário pobre, mais para estudantes. Mas é que o vocabulário das pessoas está empobrecido enormemente devido às escolas péssimas e a uma televisão criminosa, emburrecedora. Depois, alguém idiota e mal informado, disse-lhe que eu uso gíria dos anos setenta em "Leão-de-Chácara". São outros que precisam passar sal na bunda ou frequentarem botequins, muquinfos e cafofos de Copacabana, Lapa, Mangue ou mesmo do Largo do Osasco, aí em São Paulo. Claro, devem ser uns merdalhas desses que fazem universidade e que, além de curtos de intelecto, da merda da vida cachorra das ruas não sabem nada. A gíria que uso em “Leão-de-Chácara”... Aliás, essa gente é cada vez mais sabida e mais quiquiriqui para mim. Quero distância deles. São uns sabidos e sambudos, não são sambeiros e nem sambistas. Vivem no Rio e não sabem o que é um gurufim. Jamais entraram num Bofetada, num Baixaria, num Beco da Fome, num Cu Sujo ou num Pato Maluco. E é muito bom, até pra eles mesmos, que nem entrem. Aquilo é pra Dostoiévski, Buñuel, Samuel Beckett, Faulkner, Cervantes, Goya, Rabelais e que tais. Kurosawa e Genet e o Divino Marquês de Sade, por aí. Lambam sabão, mijões. A barra não é pro lero de vocês, coiós. Não se metam a desmanchar casa de marimbondo, que vocês são feitos de muita areia e pouco cimento. Vocês têm mesmo é de ficar em rodinhas semifestivas de intelectualoides do tipo que fala povo-meu-povo e salve-salve e tem a velhice precoce da sempre amadorística esquerdinha-festiva-etílicacabeludo-modal-perfumada-esquisitoide-lítero-cascateira-musical. Mas um musical tão analfabeto que vive dizendo que flauta faz acorde ... (vide até alguns nomes famosos da nossa chamada música popular e que não é popular nada, não passa de coisa da classe média para a mesma classe média). Vivaços e mandriões. Impostores faturando otários desocupados e sem horizonte. Pilantrosos do partido do dar-se bem. Parlapatões de uma figa, festeiros com a grana dos outros. 
Vocês são uns ruins de chinfra, que só engambelam distraídos e incautos neste país mergulhado no ignorantismo em que um caolho pode ser rei já que a gorda maioria é cega dos dois olhos.

- Ide lamber sabão! - diria o meu profeta barbudo, magro, alto, látego na mão ossuda e rija. Profeta que os malharia no lombo com o rabo-de-tatu.

Desculpe-me o falatório, Fernando. Por hoje, chega,

Abraços,

JOÃO ANTÔNIO

P.S. Fiz um texto que estou tomando a liberdade de lhe enviar. Ele tem, até o momento, este título: "CHORO.

- para pintagol e cuíca" 7

embora não o tenha como terminado, creio que possa receber uma melhorada como, digamos, de "técnica poética". Gostaria de que v. o lesse e opinasse. Grato por tudo.

Última forma. Não está pronto, não mostrarei. Concluo que não está em estado de se mostrar.

Voltando à vaca fria, ou antes, ao carneirismo do nosso ambiente tido como letrado atual, a verdade é que a dívida da chamada arte no Brasil com uma realidade brasileira - no passado, no presente ou no futuro - aumenta dia a dia. Ao nascer de cada novo dia. O miserê toma as ruas, o arreganho da corrupção e da pouca-vergonha dos chamados políticos se ostenta e se destempera mostrando uma boca dentuça que assustaria o próprio Drácula e faria Goya repensar toda a sua pintura da fase mais braba. Um povo se debate em problemas terríveis, desempregado, subempregado, faminto, escorraçado, tomando cacete dos bandidos e da polícia ao mesmo tempo. A miséria substituiu a pobreza há muito e muito tempo. O país ameaça ruir aos nossos olhos. Os sem-terra estão aí e talvez não se esteja percebendo que podemos estar de cara a cara com um novo Canudos ou um outro Contestado. Só que agora, o buraco é mais embaixo ou em outro lugar, pois os líderes não são messiânicos e adoidados. São gente consequente e preparada nas escolas até do exterior. A chamada realidade concreta, a que se vê aí nas ruas, nos becos, nas conduções coletivas é, neste Rio de todos os janeiros, de doer, comover e mexer até com as pedras. Um prefeito fecal, o mais ladrão, o pior que a cidade já teve desde Estácio de Sá. Um governador pé-de-cana e mentiroso. Aliás, só um pormenor ostensivo e que eles escondem, safadamente - nenhum dos dois é carioca nesta terra que agasalha tudo

7 Disposição na página conforme o original. 
quanto é safadinho e picareta e patife deste país. Vive-se uma tormenta, ainda hoje, em Itaguaí, devido às enchentes e o estado do Rio é de uma esqualidez nordestina, desculpe o mau estilo redundante.

E o que a cambada que se arvora em intérpretes da realidade faz? Nada.

Olham para os próprios umbigos, egocentrados. Escrevem elogios a si mesmos nos jornais tidos como importantes, falam de suas glórias e de suas virtudes. Esquecem os fiascos que são e fingem não saber que maneirismo não é virtude. O carneirismo a que v. se refere, Fernando, entra por aí também. A omissão, a indiferença, o deixa estar pra ver como é que fica. $\mathrm{O}$ cinismo que sabe o preço de tudo e o valor de nada. $\mathrm{E}$ vai por aí. Não foi sem motivo que Machado tanto os ironizou e que Lima Barreto, menos contido, mais açodado, se mordia tanto, chiava tão alto, vergastava e denunciava sem parar.

Nos dois originais que examinei recentemente, observei que se perguntasse a seus autores em que país eles pensam estar vivendo ${ }^{8}$. Não defendo uma literatura nacionalista ou social. Nacionalismo é perigoso e literatura social não é tudo. O espaço da literatura deve estar aberto a todas as tendências e vertentes. Puxa. Mas ninguém se enxerga nesta pocilga, os cabras não entendem que estão se enfiando numa cloaca da omissão, será que ninguém nunca vai à rua, ao supermercado, pega um ônibus, um trem, olha esse povo que já nem sorri e que todos andam de saco pra lá de cheio? São caras sofridas, amassadas, cheias de necessidade e ruins de se olhar. Goya estaria fulo e trabalhando sem parar por aqui. Buñuel, então, veria que seus olvidados são pinto.

Sei que não é nada fácil se mexer, viver, sobreviver, refletir esse miserê, pois estamos em pleno caos. Uma linguagem para tudo isso é desconhecida. Deve ser tão nova e aguerrida que fica bem pra lá de insólita. Ou arrepiante. Os temas são evidentes, ostensivos, estão aí. Mas podem fugir como enguias, são ariscos exigem que se vá fundo neles. Tudo dá muito trabalho e exige muito coração e humildade, além de garra e força. V. sabe, o buraco é noutro lugar.

Bem. O que não é possível é participar desse coro bem comportado que se alegra com suas gloriazinhas de merda e até mesmo as planta nos jornais e revistas. Porra, se um sujeito é apenas o herói de si mesmo, que fique quieto. Não transforme tudo num autobiografismo indesejável, rotundo, repetitivo e calhorda.

Falei, Fernando, talvez até pelos cotovelos. Mas só completar para você o que eu entendo - ou faço um desdobramento necessário, a meu

8 Frase truncada, conforme o original. 
ver - ao redor daquilo que v. chamou de carneirismo. E, concordo, está difícil conviver com esse ambiente. Não sei até onde vai o obscurantismo atual e começa uma gananciosa safadeza.

Machado neles. Lima neles. É preciso que o espírito desses dois negros volte e baixe. Com a força estrondosa das arriadas de Ogum.

A dívida da chamada arte brasileira cresce diante do que vemos por aí.

Você sabe, e muito bem, que não me excluo da cambada de fariseus. Também eu tenho dívidas com a realidade que já vi e não passei para o papel. Ninguém é perfeito, tenho muitas dúvidas e miasmas. Muita vez, diante do meu texto, tenho a consciência de que estou perante uma boa merda. Filho de quem sou, desconfio como meu pai - a idade faz velhos e não sábios. Mas me recuso a viver num corre-corre pela própria promoção, a frequentar tudo quanto é festinha de coiós e farsantes só pra ganhar notinha no jornal, a só me preocupar com o meu umbigo que, a bem dizer, é uma das partes mais sujas do corpo.

Os caras armaram uma parranda completa. É um sindicato de cínicos a fazer de conta que não estão entendendo nada. Todos se admiram, todos se dão tapinhas nas costas, um conta uma vantagem maior que o outro. A considerar tantas importâncias, estamos com uma inflação de gênios. Ninguém lê ninguém e todos se elogiam. Todos falam mal da Academia desde que não estejam nela. Tartufos e arpagões aos montes. O país continua a sofrer do mal da melancolia da escravidão e os espertalhões se fartam com isso. É um tal de doutor, de chefia, de madame, de senhorio, de distinto que não acaba mais. O país sofre de melancolia da escravidão. A bem dizer, dois problemas não foram resolvidos até agora - a república e a escravidão. Os oligargas ${ }^{9}$ estão aí e o trabalho escravo, até de crianças, também. Todos são democratas no duro e cristãos fidedignos da boca pra fora. A esquerdose é boazinha e a direitona é tirânica . E as loas vão por aí. Passar sal na bunda ninguém quer. Ler, estudar, trabalhar pra valer, também não. Não são amantes do trabalho sério e nem de queimar as pestanas nos livros. Em cada botequim da cidade encontramos técnicos em futebol, política, economia e educação. Cada um mais sambudo que o outro. Fala-se besteira impunemente. Resolvem, na charla, todos os problemas do Brasil e não resolvem um só dos seus problemas. Não sabem sequer beber ou comer. São preguiçosos crônicos e não gostam do saber e da arte. Temem o talento e a competência, pois seria uma ameaça às bocas que conseguiram Deus mais o diabo sabem como. Vendem a alma e o corpo a preços módicos. São uns corruptos ofertados. Adulam vorazmente o primeiro poderoso que lhes aparecer à frente. Não gostam dos

9 Conforme o original. 
seus e nem de si mesmos. Estão aturdidos e mergulhados num álcool, numa maconha e numa cocaína tristes. Não merecem estar onde estão e sabem disso. Doutores de falsa fama, parlapatões sem nenhuma vergonha e metidos a saberem tudo. Não têm dúvidas, aliás, só tem dúvidas quem filosofa. Nem sabem o que seja filosofia e vivem com essa palavra na boca. Uns zés-manés precisando de lição, uns escrotinhos folgados e impunes. Falam a linguagem da moda e fora de suas curriolas são uns coiós sem sorte. Precisam viver dopados e não só de bolinhas e psicotrópicos. Sei disso. Um médico sério me contou o que receita para esses inquietos contumazes.

Esteja certo de que a minha solidão intelectual é grande. Não tenho com quem conversar. A cada novo dia, tropeço numa ignorância melada, raiada e empombada. Uma escuridão danada no meio dos que se julgam iluminados.

Abraços gerais e recomendações aos amigos e em casa, e que Deus nos acuda a todos

JOÃO ANTÔNIO 


\section{Carta 2}

\section{Copacabana, sexta-feira triste e chuvosa, 26 de abril de 1996.}

Fernando Paixão. Prezado.

Espero tenha recebido minhas coisas. Aguardo opiniões.

Deprimido e ainda cheio de dores causadas pelo computador ou pelas posições erradas em que me sento, mais uma vez fui ler o panfleto, ensaio (?) deste Julien Gracq, maestro da impertinência, irrefutável na sua grandeza. E corajoso. Estou diante de um insolente legítimo e, não interessa, se verdadeiro. Sério como um sapato apertado, diriam os ibéricos. Mas da Espanha. Estou perante uma lucidez como poucas já li. Um depoimento acima dos manuais de literatura, um grito de socorro pelas liberdades do escritor e do leitor. E que, em primeira leitura, incomoda e deprime.

Mexeu comigo e me deprimiu mais ainda. A dor física é uma aporrinhação. Estou sem praia, sem gaivota e a morena que me telefonou insistiu em não jurar amor eterno. Melhor: me tapeou mais e melhor. Eu não teria acreditado. Esse Julien Gracq, pseudônimo do inconveniente e raro Louis Poirier, professor de história, desaba sobre a minha cabeça e faz minha depressão passar de acinzentada para cinzenta.

Fere, curto e grosso. Não conheço os seus romances. Este panfleto, pequeno em tamanho, vale muito, não exatamente pelo que diz e nem pela época em que diz. Vale pelos desdobramentos, nos afunda na reflexão da crise em que vivemos neste calvário de impossibilidades para que uma literatura ou uma arte ou qualquer coisa de verdade fique de pé e permita a seu público uma opinião própria sobre qualquer coisa que lhe seja oferecida e que já lhe chega marcada pelo destino que lhe deu a imprensa, a mídia ou sei lá que mecanismo da mentiralhada chamada fama, sucesso, repercussão e outras ladainhas. Meteram-nos numa armadilha, Fernando. Só um gênio como William Shakespeare poderia furar o cerco, mas ele foi o poeta da humanidade. E transformava historinhas que noutras mãos seriam casinhos e chanchadas em peças de poesia e reflexão plurivalente e para público de todos os níveis.

Preciso, claro, fazer nova leitura do insolente e desagradável Julien Gracq. Ele abre para desdobramentos e sua atualidade é arrepiante diante da realidade do que está acontecendo com a calhordice consentida nas chamadas letras brasileiras. Talvez aqui o quadro que ele denunciou em 1950 na França seja mais patético, chato, odioso e vão. Aqui, além de termos um público desorientado, aturdido e omisso, obediente às manipulações, ainda temos a opereta bufa dos coquetéis e lançamentos com uma fauna cujas mulheres mais parecem encarnar o feminino de Drácula, pois branquelas e empetecadas de cosméticos. Gente sem sol, em 
vários sentidos. Palermas de ambos os sexos e ruidosos, fantasmões. Uns chatos, sobremodo. Sem falar na empulhação da tevê inaguentável e nos meios de divulgação, do sumiço dos críticos razoáveis. E dos leitores razoáveis. Tudo quanto é leitor que me pula à frente, falastrão é um aspirante oferecido ao panteão dos figurões. Minha solidão é sem medida.

Antes que eu blasfeme e pergunte ao Senhor das esferas por que me abandona tanto, me deixa tão sozinho e desabrigado e sujeito a tanta praga e nem sei mais como, e nem quê ${ }^{10}$. E Ele poderá ainda me responder que com W. A. Mozart deu-se pior, e o austríaco produziu tanto e era gênio desde menininho... então eu me vingo, e meto um russo num de seus momentos mais russos, fortes e gritantes que é esse Tchaikovsky do famoso concerto para violino e orquestra. Em Ré Maior. Nele o violino enlouquece e pouco se importa em guinchar ou latir ou maravilhar, é russo. Russo até a medula. E quando arrebenta a serenata para orquestra de arco, aí é que ele endoida mesmo e quer que o ocidente se dane. É russo e grita forte, baila como um mujique, um cossaco ou um maluco entregue à sua balalaica e à sua karamatskaia, e quem gostar gostou, quem não gostar vá lamber sabão. Traído pela solene melancolia irremediável de seu sangue, traído pelo temperamento grave, exuberante e cossaco? Atraiçoado pela elegância quente e por uma dor que nem o virtuosismo disfarça? Ora, um violino é um violino e tem que gemer como todo o seu fascínio. E se quiser guinchar, guinche. Desconcerte. Com a virilidade dos violinos.

Pronto. Piotr I. Tchaikovsky me vingou. Violino adonado, enjoado, soberbo, impetuoso, tinhoso. Chorão e metido, adentrado, voluntarioso. Vingador, saído.

Julien Gracq convida a profundar a impostura toda da mentiralhada em que nos meteram até a alma do nosso horizonte.

Talvez ele chegue com algum ressentimento, sabe-se lá, outros ocupavam a cena quando publicou e estavam entrincheirados em grupo, debaixo de algum ismo ou bandeira. Havia uniões pouco naturais mas passavam por uniões e ganhavam a cena. Ele terá chegado só. Não interessa, seu panfleto é de uma sinceridade respeitável e aplica-se, em atualidade, ao exame e cotejo do próprio sistema, ao cameirismo dos prêmios, certames, conferências, grupelhos, coquetéis e, em principal, a esta corja de gente feia, chata, desinteressada, que se repete e não muda um milímetro, culturesca e beócia que rodeia a chamada vida literária num país ágrafo. A sua nota final de autor em A Literatura no Estômago mata a pau. Melhormente: mata e mostra o pau.

Grato por tudo, mande-me notícias e perdoe meus humores. A título de que não sei, em nome de quem também não sei, mas vá perdoando.

10 Conforme o original. 
Haveremos de topar com um bem topado Tchaikovsky, com um telefonema de morena na tarde e, quem sabe, com algum fiapo de verdade, acima das incertezas da filosofia. Afinal, nossa literatura não é a que pensa, ela se compraz com algumas certezas da beleza, mesmo que passageira. Na primeira leitura, o panfleto de Julien Gracq me deprimiu mais; ainda assim é um escritor de bom porte. E, claro, também estava no ponto, já não aguentava mais. Saturou-se ou saturaram-no. Vomitou, mas vomitou com elegância subida. Um ponto a favor.

Abraços,

JOÃO ANTÔNIO

\section{Anexo à carta 2 \\ Olhar baço da literatura engambelada \\ João Antônio}

Há uma crise no país. Feia, a coisa.

Há uma tensão generalizada. Na cena urbana, quem não for nosso amigo é inimigo, a começar pelo vizinho, homem anônimo disputa o lugar no ônibus, na fila do banco, no elevador. Nas nossas ruas a miséria substituiu a pobreza e a penúria é legião, a violência instalou guerra nos morros antigamente cantados com veia lírica nos sambas-canção. Ah, Goya, ah, nosso senhor D. Luiz Buñuel!

Já vivemos idos do humor carioca, fagueiro, sestroso, arteiro, garrinchado e frajola, que fazia as mulheres sorrir, tocadas, afagadas e contentes, aos nossos ditos tão naturais, flama, expressão saudável da nossa alacridade e vida; nos cabe hoje amargar o travo do humor ibérico, captador impiedoso, rascante, certeiro dos disparates da irrecorrível condição humana, aquele que fala sozinho pelas ruas, louco em seu abandono. É tempo de calvário. E a inversão de valores entrou em campo.

Há desabrigo. Nas praças, cercadas de gradis altos para que não se transformem em favelas na horizontal, já trancafiadas à noite, às sete da noite em ponto.

Trancam-se as praças. Antes assim. Não se chaveassem os cadeados e as fechaduras, seriam invadidas pelos que moram, dormem, pedem, defecam e urinam e subexistem nas ruas, onde a mendigação e o mau cheiro se misturam a alcoólatras fuleiros, maltrapilhos, pivetada farroupa, bermudas e camisetas imundas, magra e mal encarada, desenraizada de todo e no abandono, velhos encardidos e zuretas, de olhar baço e perdido no horizonte e demente, muito demente. Esconde-se uma vergonha, outras saltam em seu lugar. 
Feia e grosseira, a coisa. Também no território das letras. Como num antigo samba-canção cantado por Chico Viola, Francisco Alves, que assim dizia:

\author{
"Madrugada do homem \\ banal que compra o jornal \\ e a notícia não lê"
}

O poeta de vasta quilometragem, firme calibre estético, porte e renome internacional, mesmo a voo de corvo, despacha rente. Ou denuncia, lastima, desabafa. No país ninguém lê nada. Entanto, piormente, o poeta é prêmio internacional e, decerto, sabe o que pronuncia. Sabe das palavras como um geômetra, sua obra é prova, é homem sério. E, seco, dado à economia nas expressões.

O ex-ministro da cultura, hoje na presidência da Academia Brasileira de Letras, faz um pronunciamento. O país é ágrafo. Horas-aula para os nossos estudantes minguadas, abaixo do sofrível. Nossos alunos recebendo um ensino a não resistir metade de uma análise, vão às escolas públicas mais para comer a merenda, quando a recebem, do que para estudar. Professores recebem salário de fome e, péssimo, carecem de reciclagem. Há mais tristeza nessa miséria; muita vez, narcotraficantes invadem o espaço das escolas públicas.

Filha de um executivo de multinacional, moradora de um bairro de gentes acaudaladas do Rio, a Barra da Tijuca, recebeu da professora, num dos melhores colégios, duas indicações de leitura. O romance Iracema, de José de Alencar e um livro de autoajuda de um autor da onda.

Feia, malévola e maléfica, a coisa.

Há no país a mania antiga, gasta, rançosa de se manter em evidência autores mais falados do que lidos. De Gregório de Matos Guerra a João do Rio e de Antônio Vieira a João Alphonsus ou Adolfo Caminha, passando pelas Cartas Chilenas, o rol avoluma, mais e mais, a cada ano, a massa de não-leitores. Os que não leram, mas gostaram. Ninguém leu, mas todos gostaram; não se dá conta que estamos no território da preguiça mental nada disfarçada. Está em curso a enorme vantagem de não se cultivar a curiosidade nascida das ideias próprias; e, de assim, não se correr o risco da aflição das ideias próprias. Fala a voz da experiência dos carreiristas e dos arrivistas. Todos a uma vez querem viver à sombra do boi, como o povo chama também o bem-bom comodista do caminho mais curto. Macaqueia-se à vontade, repetem-se opiniões alheias, chavões, não se estabelecem juízos próprios.

Rápidos, espertos manipuladores da mídia se fartam. Esta senhora veloz, tão tirânica quanto indigna, hiena luminosa, fazedora e dona de 
todas as opiniões dá o braço, e de braço dado, namora impostores, rufiões solertes, batedores exímios de carteira e contrafatores, e conluiada, atua à grande e dá cartas marcadas. Joga de mão.

Parranda espetacular. Para todo gosto de semostradeiros, os que adoram dar espetáculo para multidinhas do ridículo guetinho chamado cultural. E que na voz das ruas não passam de papagaios enfeitados ou de manés fogueteiros. Mas não há melodia nesse barulho, é só ronco. Um ronco pequeno.

Engana-se à larga.

Moço inteligente passando por escritor. Sentimentaloide analfabetinho fazendo-se solene, publicando livros pretensos a que chama de poesia e que pode até, com ardil politiqueiro, ganhar láurea nacional. Tagarela e gato reles de telhado aboletando-se à grande, mal lambido, empostando a voz e, quizilento, fazendo o papelão de polemista e orador brilhante. Discurseira fácil do país tropical, ô falácia vazia, ô professoral inteligência de meia-tigela, palavras, palavras, nada mais. Caricatura de um miserê espiritual palmar, emasculador e gasto, condutor da impotência, quanto e como fizeram sofrer um Lima Barreto ou um Graciliano Ramos! Pasticho ostensivo, ou mal disfarçado, de conto norte-americano e de desmilinguida produção de nouveau roman dos anos cinquenta ganham destaque de original novidadeiro na metade dos anos noventa entre as tribos dos sabidos tupis. Vêm carregados da aura esquerdizada e são cobertos de gloríola, ou da glória nada diminutiva das vítimas honrosas que sabem ao sacrifício dos oprimidos, dos perseguidos, dos torturados, dos execrados, dos sumidos e dos massacrados pela falecida recente, a ditadura políticomilitar, nefanda como toda e qualquer outra.

Situação dilemática - os motivos podem ser nobres, e são, mas daí a valerem como literatura verdadeira vai distância grande, vai a diferença grave da arte, e, em principal, do estilo. A importância do estilo, em principal, é fatídica, só com a existência dele é possível um lídimo texto que se possa chamar de literatura. Em alguns casos, ele é a mais apropriada medida da qualidade.

Calhorda bonitinho, janota e escovado, figurinha de coquetel festivalesco bancando o douto ou o preocupado, gesticulante feito animador cultural. Doutores de falsa fama, falastrões deitando regras. Maneirismo por virtude e até por estilo. Pressa por presteza, sisudez por seriedade, gatunagem por agilidade Tzmental. A hipertrofia da confusão acelera no ambiente a inversão básica dos valores. Expressões corporais e cara feia passam por seriedade. São caretas e esgares, trejeitos dos faltos de vergonha, quando nada e quando tudo, carrancas de rufião melancólico. Sobram personagens nessa ingente ausência de autores. Egos exorbitantes fervem, 
todo e qualquer bom senso perdido, vomitam a acrimônia que parece denúncia aguda e protesto insolente e não passa de dissimulação promocional, modo indireto do desespero da promoção. Engana-se bem, mercê do oportunismo mais a mediocridade ambiente. Muitas, as situações em que os campos médios acabam prevalecendo; não só nas aparentes equipes de futebol, mas nas aparentes linhas de um elenco literário. Ganham-se páginas de jornal e de revistas coloridas mais bonitas que sinceras ou consequentes. E, a bem dizer, não é seriedade que está em campo e, sim, a simulação. Somos fortes na arte do dissímulo e da eufemia, não há negar, a nossa história não deixará ninguém negar. Assim, sabidos saltitantes ou enternados e quiquiriquis pululam, lampeiros, e há um partido sambudo, virtualmente vencedor, o do dar-se bem, que leva nome de competência. Conscienciosos barrados, honestos tropeçam em dificuldades. Uma patota estabeleceu a espécie de cabala em que se engana à larga, oportunistas e arrivistas ganham dinheiro e fama.

Diante desse quadro, caricaturando simiescos, aturdidos, fátuos e tenebrosos, gestos e gestos beiram o delirante de fim-de-comédia rampeira e muitos ririam. Menos um Molière.

No conjunto bufo, incultura generalizada. Pronunciações erradas e péssimo uso do idioma, palavrada e cacofonias grosseiras facilmente evitáveis, jargão exclamativo e imbecilzinho da moda, sintaxe mutilada e manquitola, giriazinha bocó e mediocrizante da mutilada classe média, surgida sem quê nem para quê, vazia de espírito e dessemelhante, na essência, da gíria dos marginalizados, gramática torta, troncha e regência ausente, esqualidez de vocabulário - por vezes repetidas mesmo na boca de homens públicos em plena televisão para milhões de telespectadores, e a quem a mínima boa educação e a civilidade democrática recomendam tratar por excelência - toda essa mixórdia enfezada, encachorrada de aproveitadores e de bocas-abertas pode, dizem, ter aquilo a que agora xingam, com impropriedade, de charme, para a humilhação covarde de um golpe baixo no idioma límpido de Montaigne, Pascal, Racine e Guy de Maupassant.

A mediocridade organizada é uma elevatória para o poder. E ai de quem tiver vero talento. A bem dizer, talento como caráter atrapalham no ambiente, não detêm as vantagens epidérmicas e de efeito imediato do arrivismo.

Trabalhar valente, qual o quê. Longo e difícil, duro, honesto trabalho silente de escrever, dignifica artistas como Paul Valéry ou Graciliano Ramos que exortam - "se fosse necessário gravar na pedra rija, a Literatura seria outra coisa" (P. Valéry) ou "Desconfiava dos livros, que papel aguenta muita lorota" (Graciliano em Infância) - Apud Homero sentia em República das Letras - foi atalhado, num golpe. A facilitação vige. 
Houve um tempo em que se execrou a lei abominosa do mínimo esforç, hoje corre e voga a lei do esforço nenhum. E a gana pela gloriazinha, pelos prêmios de arrumação, pela pose, pela firula egocentrada, pelo retrato no jornal, pela notinha no jornal, tudo isso tem pressa. Um provincianismo pequeno e gasto, que dá evidência e fornece aquilo a que agora se xinga de status. Arrumação aberrante de profissionais da potoca. Um provincianismo gasto e pequeno. Pequeno, baixo e cheio de pressa. A pressa da barata tonta em dia de calor elevado.

Há bem pouca novidade debaixo desse sol e muita aflição de espírito nessa tagarelice tropical. Postos na rua, entre a arraia miúda, seriam chamados, com desprezo, de muquiranas, sangues ruins e fominhas.

Esqueceu-se de que a preguiça pode ser o travesseiro do diabo e deitar tudo a perder.

Nesta atmosfera, o não-literário engendra, engambela, dissimula, mancomuna, conspira, gadanha, manobra com habilidade o apelidado sucesso e arromba o espaço do literário. O seu caminho, esperto, foi armado, futriqueiro ladino, enrustido, misterioso e lábil, cabalando, minando em passos e estratégias profissionais. Não aguentaria um tranco substancial, por macunaímico: falta-lhe todo e qualquer caráter, exceto o da má índole e da potencial iniquidade. Entanto, impera num todo de ignorantismo. Reina.

Do noticiário do quadrilátero luminoso da tevê, o acontecimento literário foi banido. Evite-se, por não "política", toda e qualquer crítica àquele animador noturno de televisão comercial, pois, se lembra de entrevistar escritores ou artistas de alguma independência - alguma sempre resta, é residual e de tudo fica um pouco, diria o poeta. Criticar, não; seria erro mortal, versão fatídica. Bater-se-ia uma porta das poucas remanescentes, e ficaria fechada hermeticamente. Decerto para todo o sempre.

Outra hipertrofia, a da promoção, montou seus holofotes e aqueles que querem aparecer, muitos ou maioria, que ninguém é tolo, nem nada, levantam o pescoço afoito, pedem com os olhos, gritam em coro: "Olhe, estou aqui! E estou aqui de novo! Como na semana passada, ainda estou aqui!”

Insuportável no quadro grotesco e doloroso é a apologia do escritor ignorante. Ora, pinóia, não se pode xingar de "elitista" alguém que confessa gostar da literatura de Clarice Lispector, João Guimarães Rosa ou Ítalo Svevo, Robert Musil ou de Marcel Proust. Da prosa primorosa de Racine ou do pensamento de Blaise Pascal, ou da monumentalidade do estilo de Euclides da Cunha. Possível, desejável e mesmo democrático que alguém possa gostar sinceramente de Corelli, Bach, Vivaldi, Mozart, Tomaso Albinoni, Liszt, Beethoven, Villa Lobos e igualmente de Noel Rosa, Dorival Caymmi, Jackson do Pandeiro, Pixinguinha, Benedito 
Lacerda, Nélson Cavaquinho, Garoto ou João Pernambuco. Para mim, estou pisando terreno do óbvio, me desculpem.

Impossível, sim, a aceitação do ignorantismo, que a tal mídia planta e promove em nome de um mercado de vendas. E se desdobra, abrangente, para as bandas de instituições que deveriam, mesmo por questão de ordem, atuarem como geradoras de ideias e do saber.

Um escritor fala na universidade, a convite. Referencia alguns gregos, apenas de passagem, para ilustração - Aristófanes, Sófocles, Ésquilo, Píndaro, Tucídides, Eurípedes, Heródoto. Logo é alertado pelo chefe do departamento de letras que o convidou. Baixe-se o nível da conversa, ali ninguém leu os gregos. E nem os romanos. Não se fale em Ovídio, em Virgílio ou em Petrônio. Esses passam a indesejáveis, por desconhecidos.

Nesse andar, há momentos em que ser chamado de intelectual, de trabalhador intelectual, é quase um insulto, um xingamento.

Chegamos, no país, igualmente à hipertrofia da inversão de valores. É de se perguntar, quais são, afinal, as regras do jogo. O chamado mercado é para forjar ou privilegiar boçais, mediocrões, incautos, manipulados e ignorantaços engambelados e engambelando-se?

Estamos longe, e bem, das perspectivas de construção de um país de homens livres e cultos.

A não-literatura ameaça, vai tomar conta.

A mim, entre outras, me tem sido imputado o ato maníaco de criar palavras e exorbitar no uso da gíria. Dia desses, pedi a um desses "leitores" anotasse as tais palavras de minha criação. Afinal, não me julgo tão rico ou inventor. Aborreço a falsa modéstia, de ordinário deslavada e sonsa demagogia. Cada um se esforce e conheça os seus limites.

Lá vem a lista de algumas palavras “inventadas" por mim. Lêse: esbórnia, crisol, xumbregar, cutuba, engambelar, coisar, murro, estrambótico, moncoso, escalafobético, tropo, tendepá, gurufim, tropicar, patuleia, boiquira, curema, emoliente, parlapatão, arrepelar, arreglo, espeloteado, parranda, espaventar. Ora, dessa vintena e pouquinho, apenas uma expressão, gurufim, não está rigorosamente dicionarizada mesmo no nosso pequeno e, ainda assim útil, Aurélio.

Há muito de amedrontador nessa não-literatura através de seus sucessos engendrados. Bastantes remandiolas, pouca-vergonha sobejando, correndo impune, como se diz nos morros. Há perigo nesse barulho e nessa confusão. Um retrocesso de qualidade está à vista, medonho.

Garanto, juro. A literatura nada tem a ver com essas coisas, tanto quanto essas coisas nada têm a ver com ela. 


\section{Carta 3}

\section{Copacabana, 04 de junho, como passa o ano, 1996.}

Fernando Paixão. Prezado.

Frio abominável e imoral. Choveu o domingo todo, esfriou muito e estou com o corpo todo doendo, detesto o frio. Para mim, tudo abaixo dos 25 graus é Sibéria e é fácil, fácil entender o quanto, bicho mouro e tropical, sofri na Alemanha. Bicho mouro e tropical.

Recebo seu bilhete, grato. Mas sinceramente, Fernando, como a sua letra é miserável e ilegível, garranchada, minha Nossa! Autêntico horror, eta letra difícil, danada de ser decifrada, hieroglífica. Quase tão ruim e enigmática quanto letra de médico. Pobre de quem, além de sofrer neste mundo, ainda tiver de trabalhar lendo a sua letra feia. Feia, tão feia a ponto de ser mais feia que a minha.

Claro que Olhar Baço é só o começo de uma vomitada. A discussão requer serenidade, exige argumentação etc. Você tem toda a razão. É, o texto que lhe enviei, apenas o começo da vomitada. E você não é um engomado. Não fique com muita interrogação e dúvidas sobre si mesmo e sobre suas opiniões - deixe as dúvidas para os filósofos. Existem para isso.

Já gostei do seu livro de poemas Poesia a Gente Inventa. Acho que pega o jeito brincado de ser das crianças e é alegre. Creio que criança deve gostar também do livro. V. já ouviu a opinião delas? Sou ruim para opinar, pois, muita vez, vejo que ainda continuo criança - o que me assusta um pouco e também é muito bom. E, como diria um personagem meu, ao ver uma mulher, logo me ocorre pedir um pouco de colo. Se for crioula, morena ou mulata, então, a vontade é inevitável. Pedir aconchego. Mouro e tropical.

Você, Fernando, por favor, me ajude. Ensine-me o caminho das pedras. Faça-me o questionário, longo, perguntando coisas, cutucando, puxando conversa. Se eu não for motivado por perguntas e questionamentos não escreverei o livro que v. quer sobre literatura. Eu me conheço, me perdoe. Até porque já ando farto, desculpe lhe dizer, de literatura sobre literatura. Ou não ando farto nada. Sei que v. me entende.

Não é preguiça, mas eu preciso de uma pauta, Fernando. Mandeme um questionário com muitas perguntas sobre tudo, sobre as coisas mais primárias. Responderei e, depois, Deus e as outras forças todas ajudando, a gente monta o livro. Se v. não tiver tempo, por favor, peça a outra pessoa, um professor, um leitor, um amigo, um curioso, um estudante não relapso, ou a várias pessoas que façam as perguntas. Muitas perguntas. Sobre linguagem, estilo, inspiração, naturalmente muitas perguntas, curiosidades, questões... E, de assim, montaremos o livro. Se depender de 
mim mesmo, sozinho, Fernando, esse livro não sai. Eu me conheço para trabalhos assim. Tenho de ser motivado. Caso contrário, esse bendito livro não sairá nunca, em tempo algum. Este aqui se conhece, Fernando. Ajude-me. Preciso ser pautado para fazer um serviço desses. E conto com a sua valiosa (palavra não exagerada) ajuda. Depois, mais um favor, você coordene as perguntas com meio-começo-fim para formarem a estruturação do livro. Sei que lhe dou trabalho, lamento. Mas o que posso fazer? Você concordando ou não: João Antônio não é um sujeito, digamos, didático. Ele prefere aprender a ensinar, sei lá. É um curioso enjoado, digamos. Uma vez perguntado talvez possa dar respostas interessantes e até contundentes. Seremos também. Desde já, gratíssimo.

Patuleia e o mais que promete a minha vida literária vai trazendo jornalistas à minha procura. Esteve aqui ontem o pessoal do JB. Dizem que eu não sou badalado quanto deveria. Respondi que vou vivendo.

Sugeri ao repórter que abrisse a matéria com o título de um choro do gigantesco e nunca muito louvado santo Pixinguinha: "Vou vivendo". Porque Pixinga sabia das coisas. E quanto. Músico é um ponto acima.

Eu tenho e não tenho. Amorosamente lhes mostrei, guardo raridades, pois sou um homem dado a preciosidades e sofisticações do espírito: ouço música religiosa e quando cantam as vozes do Gospel só me falta baixar santo, leio sobre o mundo místico dos negros, fui amigo de gregos, angolanos e turcos em Berlim, tive amiga bailarina turca, mulher muito bonita e sincera, fiel a seu homem, honesta lutadora valente, não resisto a uma voz grave de crioula, tenho algum jeito escarrapachado de ser e carinho enorme pelas coisas, pessoas e animais que amo, pintagol, pintassilgo, gaivota, disco antigo de Aracy de Almeida, a velha Araca, tão sambeira e debochada, tão mulata da Zona Norte, tão da minha laia, disco de Noel com capa de Di Cavalcanti; outro que também não podia ver uma negra bonita e por amá-las, pintou-as. Carnudas. E de olhar meio para o esverdeado. E na parede eu penduro um Pixinguinha, raro, com dezessete anos de idade, mocinho, mocinho, e seu-instrumento de chorista era a flauta.

Agora, a revisão do livro está ruim, você viu? Ia-me esquecendo:

Moóca, nome do bairro, leva acento, não? Em “Patuleia” aparece sem acento. Verifique, por favor. O livro está precisando de uma revisão nova, concorda?

Não quero chatear, pois sei o quanto v. é operário ocupado. Mas também na edição que a Ática fez do conto-título, Malagueta, Perus e Bacanaço, coleção Rosa dos Ventos, faltou a dedicatória a Carne Frita, a que aparece na edição original no bloco de contos Sinuca. O pessoal que me 
lê reclama isso. O jornalista do JB que esteve aqui ontem, Cláudio Cordovil, é um que conhece os meus escritos, acompanha tudo e me reclamou isso. Aliás, este mundo é grande e pequeno, diria o poeta. O tal jornalista, Cláudio Cordovil, acabou ficando aqui três (3) horas e, comovido, me revelou ser sobrinho em primeiro grau de Tijuquinha, sinuqueiro famoso, que já morreu e foi meu camarada nas rodas da Lapa e do Passeio Público. Usava bigode frajola e tinha jeito maneiro e cavalheiresco, dissimulado, falava baixo, educado, como alguns sinuqueiros da antiga. O mulherio dizia que um homem assim as levava ao céu. Na mesa, um mordedor. Imagine, baixar aqui no tugúrio e falso mirante, um sobrinho de Tijuquinha, o Edmir falado. Não há um jeito de, nas próximas tiragens de Malagueta, Perus e Bacanaço, a gente incluir a dedicatória para Carne Frita? Obrigado - há mais de 30 anos, lembro-me, a dedicatória foi muito elogiada por João Alexandre Barbosa. Num artigo que ele escreveu no Jornal do Comércio. Do Recife. Quando ele morava na Rua dos Navegantes. Eu me lembro muito bem.

Fernando, me compreenda e me ajude, queira-me bem que é para Deus lhe ajudar. De mais a mais, querer bem não paga imposto. Garanto. Abraços agradecidos, recomendações em casa

João Antônio 